\title{
The Concept of State Responsibility in Fulfilling the Rights of Persons with Disabilities in the Manpower Sector in Indonesia
}

\author{
Warsono* and Mashari
}

\author{
Faculty of Law, Universitas 17 Agustus 1945, Semarang City, Pawiyatan Luhur Street, Bendan Dhuwur, \\ Semarang City, Indonesia
}

\begin{abstract}
This study aims to analyze the implementation of state responsibilities in fulfilling the rights of persons with disabilities in the field of employment in Indonesia and the supporting and inhibiting factors of the state in fulfilling the rights of persons with disabilities in the field of employment. The method used in this research is normative legal research, with legal studies using legal systematics, research that will synchronize regulations, and make comparisons with applicable laws and use legal history. The study results found that the state fulfills the rights of persons with disabilities in the field of employment by providing protection and fulfillment of the rights of persons with disabilities. Supporting factors for social movements in voicing the fulfillment of the rights of persons with disabilities, which are accommodated by the Indonesian Association of Persons with Disabilities, are supporting factors for the fulfillment of facilities for persons with disabilities in public spaces. The inhibiting factor is that the fulfillment of the rights of people with other disabilities is still lacking; it is proven that facilities for people with disabilities often make the facilities that have been built at several points ineffective and ineffective. The concept of state responsibility in fulfilling the rights of persons with disabilities in the field of employment in Indonesia to obtain work and a decent living for humanity is a constitutional right guaranteed in the 1945 Constitution of the Republic of Indonesia.
\end{abstract}

Keywords: State Responsibility, Rights of Persons with Disabilities, Employment.

\section{INTRODUCTION}

The State of Indonesia is a welfare state based on law; as stated in Article 1 paragraph (3) of the 1945 Constitution of the Republic of Indonesia, the State of Indonesia is a state of law. In principle, everything is regulated by legal norms so that justice can be realized in the community. In maintaining the principle of the rule of law, the government must be fair in Indonesian society, namely the fulfillment of facilities and infrastructure that can be efficient and effective for the community. The existence of facilities and infrastructure is an integral part of achieving justice in the community. Humans are created not all born in a perfect state; physical limitations are called disabilities, such as those who cannot see, cannot walk, cannot speak, etc (Tibaka \& Rosdian , 2017).

Persons with Disabilities have long-term physical, mental, intellectual, or sensory limitations, which can experience their full and effective participation in society on an equal basis with others when faced with various barriers. According to age, persons with disabilities are divided into 2, namely, Children with Disabilities and adults with disabilities. A Child with Disabilities is a person who is not yet eighteen years of age who has a physical or mental disorder that can interfere or become an obstacle and obstacle for him to

*Address correspondence to this author at the Faculty of Law, Universitas 17 Agustus 1945, Semarang City, Pawiyatan Luhur Street, Bendan Dhuwur, Semarang City, Indonesia; E-mail: warsono2594@yahoo.com carry out his physical, spiritual, and social functions properly, consisting of children with physical disabilities, mental disabilities, and children with physical and mental disabilities. Meanwhile, an adult person with a disability is someone who is 18 years of age and over (Sumanjoyo Hutagalung \& Faedlulloh, 2021).

The regulation of Persons with Disabilities is found explicitly in Law Number 8 of 2018 concerning Persons with Disabilities. Article 1 paragraph 1 states that persons with disabilities are any person who experiences physical, intellectual, mental, and sensory limitations for an extended period in interacting with the environment can experience obstacles and difficulties to participate fully. Based on the Ministry of Social Affairs of the Republic of Indonesia in 2018, the number of people with disabilities in Indonesia was 152,149 people (Dewi, 2019).

According to Harry Hikmat (2020), as the DirectorGeneral of Social Rehabilitation of the Ministry of Social Affairs of the Republic of Indonesia conveyed several data sources related to persons with disabilities. In the 2018 National Socio-Economic Survey, 14.2 percent of Indonesia's population with disabilities or 30.38 million people. Data from the Ministry of Social Affairs, which contains integrated social welfare data in January 2020, can describe socio-economic status, which is essentially needed to address various socio-economic problems, vulnerabilities, and welfare issues. Integrated social 
welfare data is a system that can be used for program planning and to identify the names and addresses of recipients; there are 1.3 million people with disabilities. Based on data from the information system for Persons with Disabilities in March 2020, there were 197,582 people with disabilities. Globally, the WHO World Report on Disability in June 2011 showed that there were 1.1 billion people with disabilities worldwide. About 15 percent of the world's population lives with some form of disability, 2-6 percent of whom experience significant difficulties in functioning.

The Central Government's authority as regulated in Article 4 paragraph (1) of the 1945 Constitution of the Republic of Indonesia and the Regional Government's authority as regulated in Article 65 paragraph (1) letter an of Law Number 23 of 2014 concerning Regional Government. The government's authority should be in line with its implementation so that people with disabilities also feel justice. An example of the fulfillment of facilities for persons with disabilities is regulated in Article 25 paragraph (1) letter g of Law Number 22 of 2009 concerning Road Traffic and Transportation, namely every road used for public traffic must be equipped with road equipment in the form of facilities including for persons with disabilities (Zaman, 2017).

The government is obliged to build infrastructure for persons with disabilities, but they still feel the facilities are not friendly. The Director-General of Prevention and Control of the Ministry of Health of the Republic of Indonesia said that currently, the various needs of persons with disabilities had not been fully met. There needs to be seriousness in providing justice to the disabled. The government, as the holder of power in fulfilling the infrastructure, must also be responsible. Local governments must also be responsible for providing facilities and infrastructure for persons with disabilities (Latuconsina, 2014).

Research This author focuses on the study of the responsibilities of the Central Government and Local Governments in fulfilling the rights of persons with disabilities in Indonesia as the basis for regulating essential services for the rights of every citizen, including persons with disabilities. This research is based on the theory of previous research that has a different focus of study: Zulfah Latuconsina, with the title Affirmation of Government Policy in Work Facilities for Persons with Disabilities. The study discusses the Central Java Provincial Government in responding to people with disabilities, especially disabled workers.
Fanny Priscyllia, with the title Legal Studies on Public Service Facilities for Persons with Disabilities. The research discusses the responsibility of the state towards persons with disabilities in Indonesia. The results of the study stated that basic services for the rights of every citizen, including persons with disabilities, are the responsibility of the state. The government has guaranteed some accessibility of facilities for persons with disabilities through several policies (Priscyllia, 2016).

Indonesia has built a better understanding of the Rights of Persons with Disabilities with the enactment of Law Number 8 of 2016, following the ratification of Persons with Disabilities through Law Number 19 of 2011, which revised Law Number 4 of 1997 and shifted from the perspective of "twelve " roast' to an "empowerment" perspective in viewing persons with disabilities. In-Law Number 19 of 2011, it is obligatory to involve Persons with Disabilities in all aspects of life, including economic activities. The number of articles in Law Number 19 of 2011 has increased from 51 to 153 , reflecting better guarantees in ensuring the rights of Persons with Disabilities. The concept of responsibility of the Central Government is solid seen in Article 4 Paragraph (1) of the 1945 Constitution of the Republic of Indonesia and the authority of the government under it, namely the Regional Government as referred to in Article 65 Paragraph (1) letter a of Law Number 23 of 2014 concerning Regional Government. . The authority of the government should be in line with its implementation so that people with disabilities also feel justice.

\section{METHODS}

This research uses normative legal research methods. Normative legal research is a legal study that applies norms or library materials as a basis for arguing. As a legal force in normative research by applying legal principles, the application in research using legal systematics, research that will synchronize regulations vertically and horizontally, and comparisons to applicable laws and legal history (Soekanto \& Mamudji, 2011).

This study uses a legal norm approach, namely the applicable laws and regulations. Approach with laws and regulations to comprehensively determine the regulations used related to the issues studied, whether consistency, difference, or conformity between one legal norm and another (Marzuki, 2010). The juridical approach is based on a normative approach where 
research is in the form of an in concreto legal discovery effort that can be applied to resolve a particular legal case and analyze various laws and regulations (Nugroho \& Noho, 2020).

The nature of this research is prescriptive or based on applicable regulations. Researchers will describe the problems that occur based on laws and regulations relevant to persons with disabilities. The problems answered will provide a conclusion that will be the common thread of the formulation of the problem in the study. In addition, researchers can provide recommendations or input from the results obtained in the research conducted.

\section{RESULTS AND DISCUSSION}

\section{The State in Fulfilling the Rights of Persons with Disabilities in the Manpower Sector}

The workforce sector is one of the essential fields to advance a nation's economy. The business in question is the provision of sufficient employment opportunities to increase the number of workers entering the labor market. Job opportunities are one of the main problems facing Indonesia today. Job opportunities can be interpreted as the demand for labor in the labor market, where the workplace must be equal to the number of available workforce vacancies in the world of work. The expansion of labor absorption is needed to accelerate the growth of the young population entering the labor market. The imbalance between labor force growth and employment will lead to high numbers.

According to Mulyadi (2003), labor is the population of working age (aged 15-64 years) or the number of residents in a country who can produce goods and services. Absorption of labor is the number of jobs that have been filled that are available from the number of working people. The working population is absorbed and scattered in various sectors of the economy. The absorption of the population works because of the demand for labor. Absorption of energy can be regarded as the demand for labor.

Persons with Disabilities in fulfilling their rights in employment have not yet received a place in society. The limitations they have, make them considered a vulnerable group, helpless and in need of mercy. Their rights as human beings are often ignored. They are starting from the right to live, getting a job, and obtaining education and health services to the right to access facilities to public facilities. The 1945 Constitution of the Republic of Indonesia has firmly guaranteed people with disabilities. At least in Article $28 \mathrm{H}$ paragraph (2), it states that "Everyone has the right to get special facilities and treatment to obtain the same opportunities and benefits to achieve equality and justice." In addition, the Indonesian government has also ratified the Convention on the Rights of Persons with Disabilities in 2011, which was started in Law Number 19 of 2011 concerning the Convention on the Ratification of the Rights of Persons with Disabilities. Indonesia is the 107 th country to ratify the Convention.

Based on Law Number 19 of 2001, the rights of persons with disabilities are regulated. They start from the right to be free from torture, a cruel treatment that is inhumane and degrading to human dignity, to the right to be free from exploitation, violence, and arbitrary treatment. Persons with disabilities are also entitled to respect for their mental and physical integrity based on equality with others, including the right to obtain protection and social services in the context of independence and an emergency.

In ensuring the fulfillment of the rights of persons with disabilities, the government issued Law Number 18 of 2016 concerning Persons with Disabilities. The Law on Persons with Disabilities is a legal umbrella for persons with disabilities and guarantees that people with disabilities are protected from all forms of injustice, violence, and discrimination. Law Number 18 of 2016 concerning Persons with Disabilities regulates the variety of Persons with Disabilities, the rights of Persons with Disabilities, the implementation of respect, protection, and fulfillment of the rights of Persons with Disabilities. The existence of this law will strengthen the rights and better opportunities for persons with disabilities. Starting from the right to life, the right to get a decent job, better education, and easy access to public facilities (Nazifah, Gede Sudika Mangku, \& Putu R, 2021).

Implementation of Law Number 18 of 2016 concerning Persons with Disabilities, the government is currently preparing 8 Draft Presidential Regulations, including the fulfillment of the Social Rehabilitation Rights of Persons with Disabilities; Adequate Accommodation for Persons with Disabilities in the Judicial Process; Habilitation and Rehabilitation Services for Persons with Disabilities, Adequate Accommodation for Students with Disabilities, Concessions, and Incentives in Respect. The government has also prepared a Draft Presidential Regulation concerning the Protection and Fulfillment of 
the Rights of Persons with Disabilities; Planning, Implementation, and Evaluation of the Respect, Protection and Fulfillment of the Rights of Persons with Disabilities. The government is currently preparing the Draft Presidential Regulation on the Fulfillment of the Right to Housing, Public Services and Disaster Protection with Access for Persons with Disabilities and the Draft Presidential Regulation on the Disability Service Unit in Employment (Nurvianti, 2017).

The government has developed several programs to protect people with disabilities, namely the Assistance Program for Persons with Severe Disabilities. During the last four years, this program has assisted as many as 71,448 people. There is also a particular Family Hope program for people with disabilities. Until now, there have been 73,932 persons with disabilities who have received assistance from this program. The government has assisted 3,164 people with disabilities

As the administrator of government, the government has the duty and function to provide welfare to its people. The government carries out these duties and functions from the center to the regional levels based on their power or authority. The government provides an obligation to provide facilities for persons with disabilities in several open areas. The local government in East Kalimantan has initiated this responsibility by making the Regional Regulation of the Province of East Kalimantan Number 1 of 2018 concerning the Protection and Fulfillment of the Rights of Persons with Disabilities. In this case, those who play an active role in fulfilling these facilities are the Department of Public Works and City Planning in several local governments. In terms of fulfilling facilities, the Public Works and City Planning Office usually coordinates with the Social Service as the unit in charge of social affairs, including persons with disabilities.

The interviews conducted by the author with related parties show that the fulfillment of disability facilities in Indonesia is available in various public spaces but is still very limited. The availability of facilities for persons with disabilities is usually found in government office facilities, worship facilities built using the Regional Revenue and Expenditure Budget, and regionally owned educational services such as schools and public libraries. Meanwhile, the availability of facilities for persons with disabilities in some public facilities such as recreational parks and sports facilities is not as complete as others. Local governments should pay more attention to these facilities for persons with disabilities seriously.

The Policy for the Fulfillment of the Rights of Persons with Disabilities plays a vital role in the policy. Policies are those that are officially recognized as individuals or institutions responsible for implementing programs in the field. Implementing the Policy for the Fulfillment of the Rights of Persons with Disabilities are all agencies with their respective main task and functions. The office in charge of the Policy for the Fulfillment of the Rights of Persons with Disabilities in the Manpower Division is the Manpower Office. In Central Java and Indonesia, the Department of Social Affairs also trained workers, although the activities were not organized. The Manpower and Transmigration Office of Central Java Province also conducts job training for persons with disabilities in Indonesia (Simanjunta, 2021).

The quota for government agencies to employ persons with disabilities is $1 \%$, but in Law Number 8 of 2016 concerning Persons with Disabilities, it is $2 \%$. In both regulations, the quota for companies is the same, namely $1 \%$. The study results indicate that the Government of Indonesia does not yet have a mayoral regulation regarding the fulfillment of the rights of persons with disabilities in Indonesia. In carrying out its primary functions in the fulfillment of the rights of people with disabilities, the Indonesian Social Service refers to the Central Java Regional Regulation Number 11 of 2014 concerning the fulfillment of the rights of people with disabilities. Meanwhile, the Indonesian Manpower and Transmigration Office is just starting to fulfill the rights of persons with disabilities according to their primary functions, such as providing training for workers with disabilities in 2018 and implementing policies that refer to Law Number 8 of 2014 concerning Persons with Disabilities. The $1 \%$ quota for persons with disabilities in Indonesia is still not fulfilled (Fatria \& Sardi, 2020).

Based on data from 752 companies in Indonesia, only five companies have employed workers with disabilities. The five companies that have employed persons with disabilities also have not met the $1 \%$ quota as stated in the Central Java Regional Regulation Number 11 of 2014 concerning the Fulfillment of the Rights of Persons with Disabilities. Training/empowerment has been carried out by the Department of Manpower and Transmigration of Central Java Province in Indonesia every year, but the drawback is that the training or empowerment carried 
out is still monotonous and does not attract market interest. The number of participants is still limited to 4-5 packages, and each training package has been set at 20 people.

\section{Supporting and Inhibiting Factors of the State in Fulfilling the Rights of Persons with Disabilities in the Manpower Sector}

The condition of providing facilities for persons with disabilities should be a severe concern for policymakers. The supporting factor for the fulfillment of potential disability facilities is civil society's attention so that it can pressure policymakers at the executive and legislative levels to immediately make a local legal basis (Regional Regulations) regarding the fulfillment of the rights of persons with disabilities. This can be seen from the initiation of regional regulations, which have undergone a relatively rapid process since Law Number 8 of 2016 was enacted.

Persons with Disabilities, even though they have a legal umbrella, discrimination still occurs for people with disabilities. One sector that is prone to discrimination in education. An example is a mechanism for the National Selection of State Universities in 2014. For example, it still lists prospective students who must not be blind, deaf, speech impaired, and color blind. As a result, people with disabilities are unable to continue their education to college. Data from the Central Statistics Agency in 2015 stated that only 36.49 percent of people with disabilities aged 5-29 years went to school, 41.89 percent dropped out of school, and 21.61 percent never went to school (Dwi Agustiningsih \& Rusmana, 2017).

Supporting factors in fulfilling the rights of persons with disabilities to all children have equal opportunities to develop their potential in the same environment actively. Inclusive education, people with disabilities will make them accustomed to interacting with other people with disabilities. Inclusive education also shows the recognition and appreciation of diversity. Inclusive education is non-discriminatory education. Inclusive education has the principle of being open, nondiscriminatory, responsive to any differences, relevant and accommodating to the way of learning, and centered on the needs and uniqueness of students.

Based on data from the Directorate General of Primary and Secondary Education Management, Ministry of Education and Culture, up to 2010, the number of schools providing inclusive education was 814 schools with 15,181 students. The fulfillment of the right to education for persons with disabilities through inclusive education has also been felt by the local community. Several local governments have implemented much inclusive education. Several cities declare as inclusive cities (Pratomo Andi Widodo, Hufad, \& Sunardi , 2019).

The inhibiting factor in fulfilling the rights of persons with disabilities is the provision of funds. The existing budget is poorly distributed or not maximized for the provision of facilities for persons with disabilities. Academic studies on disability are less dynamic so that public buildings with disability facilities do not meet the standards for planning special public facilities for persons with disabilities. The government's acceleration and concentration in fulfilling facilities for people with disabilities will be more measurable and maintained if it gets encouragement and attention from the wider community.

In fulfilling the rights of persons with disabilities who tend to have difficulty making friends. Richard Rieser found that various cases occurred in inclusive schools, where children with disabilities became the object of ridicule from their friends. The most frequent challenge is that the curriculum in inclusive schools, such as materials, methods, and learning evaluation systems, is still discriminatory against children with disabilities. Adjustment and accommodation in the curriculum, children with disabilities, will find it difficult to follow the learning process in inclusive schools.

\section{The Concept of State Responsibility in Fulfilling the Rights of Persons with Disabilities in the Manpower Sector in Indonesia}

In line with previous research on disability and labor force participation or recruitment rates, persons with mild and severe disabilities have significantly lower labor force participation rates. Difficulties for Persons with Disabilities to enter the workforce may be caused by several discriminations faced by Persons with Disabilities, namely institutional discrimination, discrimination in the physical environment, and social discrimination.

The unemployment rate of persons with mild disabilities is lower than that of Non-Disabled persons, while the unemployment rate of persons with severe disabilities is higher than that of Non-Disabled Persons. These statistics show that once people with mild 
disabilities enter the workforce, it is easier for them to find work than people with severe disabilities. This may be due to the worse condition of persons with severe disabilities so that they have lower abilities, which results in lower job options. As a result of lower job choices, people with severe disabilities have higher unemployment rates than people with mild disabilities or non-disabled.

Most Persons with Disabilities work in agriculture, plantation, forestry, and fisheries. The percentage of Persons with Disabilities in these sectors is almost twice as high as that of Non-Persons with Disabilities $(46.01 \%$ versus $29.51 \%$ of Non-Persons with Disabilities). Regarding employment status, almost half of PWOD work as employees (approximately 40.11\%). This statistic is much higher than the percentage of persons with mild and severe disabilities who work as employees, 21.93 percent for the former and 12.16 percent for the latter. Disability seems to be a burden for Persons with Disabilities to enter the labor market as workers because of the competitive labor market. Both mild and severe disabilities tend to work as selfemployed, self-employed with temporary or unpaid workers, and unpaid workers or family workers (Halimatussadiaha \& Etc, 2017).

Everyone has the right to get a job. Data from the Social Welfare Data and Information Center of the Ministry of Social Affairs stated that in 2012, the number of people with disabilities in Indonesia was $1,250,780$ people. They consist of physically disabled, blind, deaf, and mentally disabled persons. Ironically, from the number of people with disabilities, not all of them can get a job. Opportunities for persons with disabilities to find work are still meager. Data from the Directorate General of Manpower Placement Development states that in 2014 the number of people with disabilities who did not work was 1.5 million people. Meanwhile, the data collection results conducted by the Data and Information Center of the Ministry of Social Affairs in 2008 recorded that $74.4 \%$ of persons with disabilities were unemployed or not working, and $25.6 \%$ of persons with disabilities had jobs. The types of work that are often undertaken are farmers, laborers, and services.

Article 53 paragraph (1) of Law Number 18 of 2016 concerning Persons with Disabilities states that the government, regional governments, state-owned enterprises are required to employ at least 2 percent of people with disabilities from the total number of employees. Furthermore, in paragraph (2), it is stated that private companies must employ at least one percent of people with disabilities from the total number of workers. Several factors cause people with disabilities do not to have the opportunity to work (Tri Anomsari \& Widharetno Mursali, 2020).

The research conducted by Susilowati stated that companies do not employ people with disabilities because companies do not have sufficient information about how companies can recruit workers with disabilities, especially people with disabilities who have skills that match the company's needs. In addition, there is still a misunderstanding about workers with disabilities who are considered a burden on the company. In fact, according to a report released by the ILO (2011), ignoring the productive potential of persons with disabilities in the world of work results in losses for the community and even the country. The ILO estimates that as much as 3 to 7 percent of the productivity of persons with disabilities affects the national Gross Domestic Product. In fact, according to Roberge, Lewicki, Hietapelto, and Abdyldaeva (2011), the management of workforce for persons with disabilities, if appropriately implemented, will have a significant influence on the progress of the company, either through increasing employee loyalty, improving the company's image, expanding the market, and decreasing absenteeism. And employee turnover.

In providing remuneration, the company also upholds the principles of justice and equality, where all employees are paid based on the regional minimum wage and their performance during work. The company also recognizes and appreciates the potential benefits obtained from employees with disabilities, such as good personalities, special work skills, increasing product sales, creating a friendly work environment, and enhancing the company's image.

Through the Angkasa internship program, PT. Trans Retail Indonesia has also made efforts to empower people with disabilities. They are introduced to the world of work, retail business management systems, and other technical matters. This is useful for printing people with disabilities into ready-to-use employees with skills that match retail businesses such as Carrefour. In terms of providing accessibility, PT. Trans Retail Indonesia has not fulfilled access to buildings that are friendly to persons with disabilities. Such as occupational health and safety specifically for employees with disabilities, access to buildings, roads, and transportation. This has resulted in the company having to focus on the types of deaf disabilities only. In 
addition, the study also found that there is no formal and comprehensive system for managing workers with disabilities in the company, even so, PT. Trans Retail Indonesia is considered capable of maintaining its commitment to developing workers with disabilities, although it is not yet fully inclusive. Over time, of course, the company's commitment is expected to lead to a more comprehensive management system to achieve workplace inclusion.

The concept of State Responsibility in Fulfilling the Rights of Persons with Disabilities in the Manpower Sector In Indonesia with the establishment of laws and regulations in the framework of protecting human rights, has rational reasons, as far as the rights and freedoms can be legally and proportionally limited by the State (BPHN, 2016). In addition, the state must also be able to ensure that the laws and regulations must be harmonious with each other-protection of the Rights of Persons with Disabilities in Obtaining Decent Work and Livelihood for Humanity.

The government has just passed two Government Regulations, namely, Government Regulation Number 52 of 2019 concerning the Implementation of Social Welfare for Persons with Disabilities, which is the implementation of the provisions of Article 96 of the Law on Persons with Disabilities and Government Regulation Number 70 of 2019 concerning Planning, Implementation, and Evaluation of Respect, Protection and Fulfillment of the Rights of Persons with Disabilities which is the implementation of the provisions of Article 27 paragraph (3) of the Law on Persons with Disabilities. Through Presidential Regulation Number 75 of 2015 concerning the National Action Plan for Human Rights 2015-2019, the Government of Indonesia reaffirmed its commitment to mainstreaming an inclusive approach to national development by including the National Action Plan for Persons with Disabilities in the National Action Plan for Human Rights (Kumala, 2020).

The National Development Planning Agency has also issued a "Planning and Budgeting Guidelines for Persons with Disabilities" to serve as a reference for Ministries, Institutions, and Local Governments in planning programs and budgeting by inclusive development needs (Brawijaya, 2018). All existing legal policy regulations. There is a Government Regulation relating to the rights of Persons with Disabilities. However, it is not a mandate from the Law on Persons with Disabilities but rather the implementation of the provisions of Article 44 paragraph (4) of Law Number
28 of 2018 concerning Copyright, namely Government Regulation Number 27 of 2019 concerning Facilitation of Access to Works for Persons with Disabilities in Reading and Using Braille, Audio Books and Other Facilities which was ratified on April 18, 2019. Protection of the Rights of Persons with Disabilities in Obtaining Work and a Decent Livelihood for Humanity above should be able to become a legal umbrella for the Government, Central Government, Regional Government, State-Owned Enterprises, RegionalOwned Enterprises, and Private Companies to participate in the success of the quota of employment opportunities for persons with disabilities. In addition, there is also a Memorandum of Understanding between the Ministry of Industry and the Ministry of Social Affairs regarding equal opportunities and access for persons with disabilities in the field of work in January 2019.

Accessibility of Persons with Disabilities to getting Jobs Accessibility according to Article 1 point 8 of the Law on Persons with Disabilities is facilities provided for Persons with Disabilities to realize Equal Opportunities. In Article 19 of Law Number 18 of 2016 concerning Persons with Disabilities, accessibility includes the right to a. Gaining accessibility to take advantage of public facilities; b. Get proper accommodation as a form of individual accessibility. Regarding accessibility, the state requires the Government and Local Government to provide facilities or infrastructure that Persons with Disabilities can access as one of the requirements in applying for a building permit. The emphasis on the physical environment as a significant determinant factor that causes disability has been stated in the latest concept related to disability issued by the United Nations, namely the concept of The International Classification of Functioning (ICF), Disability, and Health which replaces the concept of The International Classification of Impairments, Disabilities. and Handicaps (Tamba, 2017).

This new concept of The ICF emphasizes the interaction of 3 (three) factors on disability issues, namely "impairments" (specific abnormalities or damage in a person's body), "activity limitation" (limited activities due to certain body conditions), and "participation restrictions." (restrictions on participation, for example, discrimination at work, school, etc.). In addition to physical accessibility, there is non-physical accessibility that needs to be considered by the state regarding how information, communication, and technology can be used or understood by Persons with 
Disabilities. The commitment of the Government, Regional Government, State-Owned Enterprises sector, Regional-Owned Enterprises sector, and the private sector to comply with the provisions of Article 53 of the Law on Persons with Disabilities must be wholeheartedly supported and to realize policies on these commitments, careful planning, and data protection are required. The Rights of Persons with Disabilities to Work and Earn a Humane Livelihood 220 Journal of the Constitution, Volume 17, Number 1, March 2020, is accurate on the number of persons with disabilities each year. Talking about the presentation of data on persons with disabilities, the government, which in this case is the Ministry of Manpower, said that there are difficulties in recording the number of persons with disabilities in the workforce as well as the issue of the absence of a particular agency for labor inspectors to supervise companies, State-Owned Enterprises and Regional-Owned Enterprises that operate. have employed persons with disabilities.

\section{CONCLUSIONS}

The state fulfills the rights of persons with disabilities in the field of employment by providing protection and fulfillment of the rights of persons with disabilities. Fields that are sufficient to fulfill are limited to general education, such as libraries, and some access to government offices. Meanwhile, in other fields such as sports, tourist parks, and so on, the local government still has not maximized the fulfillment of these facilities. The existence of supporting factors for social movements in voicing the fulfillment of the rights of persons with disabilities, which is facilitated by the Indonesian Association of Persons with Disabilities in the East Kalimantan region, is a supporting factor for the fulfillment of facilities for persons with disabilities in public spaces. In addition, the community has made local governments quickly initiate steps to form regional regulations regarding the fulfillment of the rights of persons with disabilities.

The concept of state responsibility in fulfilling the rights of persons with disabilities in the field of employment in Indonesia to obtain work and a decent living for humanity is a constitutional right guaranteed in Article 27 paragraph (2) of the 1945 Constitution of the Republic of Indonesia. The government intervenes by the state or the government in carrying out the function of the welfare state, namely fulfilling the right to work and a decent living. Ratification of the Convention on the Convention on the Rights of Persons with Disabilities promulgated by Law Number
19 of 2011, Law Number 4 of 1997 concerning Persons with Disabilities as amended by Law Number 8 of 2016 concerning Disabilities is a role of the state to realize the expectations of persons with disabilities in fulfilling their rights. The state has played a role in actualizing Article 27 paragraph (2) of the 1945 Constitution of the Republic of Indonesia for persons with disabilities through the three legal instruments mentioned above.

\section{REFERENCES}

BPHN. (2016). Parameter Hak Asasi Manusia Terhadap Rancangan Peraturan Perundang-undangan. Jakarta: Balitbang Hukum dan HAM.

Brawijaya, L. B. (2018). Fiqih Penguatan Disabilitas. Jakarta: Lembaga Bahtsul Masail PBNU.

Dewi, I. I. (2019). Anti-Discrimination Inemployment Regulation For Persons With Disabilities In Indonesia. Yustisia, 8(1), 133. https://doi.org/10.20961/yustisia.v0ixx.28016

Dwi Agustiningsih, D., \& Rusmana, E. (2017). Procedures For Disability Issues In The Education Of Education In Higher Education. Ta'dib: Jurnal Pendidikan Islam, 6(1), 137-144. https://doi.org/10.29313/tjpi.v6i1.2329

Fatria, R., \& Sardi, M. (2020). Indonesian Government Policy To Provide Employment Opportunities For Persons With Disabilities. Media of Law and Sharia, 2(1), 160. https://doi.org/10.18196/mls.v2i2.11486

Halimatussadiaha, A., \& Etc. (2017). Mapping Persons With Disabilities (PWDs) In Indonesia Labor Market. Economics and Finance in Indonesia, 63(2), 135. https://doi.org/10.7454/efi.v63i2.572

Hikmat, H. (2020, Agustus 10). Data Penyandang Disabilitas. (Mashari, Interviewer)

Kumala, R. D. (2020). Legal Analysis Of Government Policy On Large Scale Social Restrictions In Handling Covid-19. The Indonesian Journal of International Clinical Legal Educatio, 2(2), 188. https://doi.org/10.15294/ijicle.v2i2.38326

Latuconsina, Z. (2014). Afirmasi Kebijakan Pemerintah Dalam Fasilitasi Kerja Bagi Penyandang Disabilitas. Pandecta, 9(2), 230.

https://doi.org/10.15294/pandecta.v9i2.3445

Marzuki, P. M. (2010). Penelitian Hukum. Jakarta: Kencana.

Nazifah, Gede Sudika Mangku, D., \& Putu R, N. (2021). Fulfillment of Labor Rights for Persons with Disabilities in Indonesia. International Journal of Criminology and Sociology, 10, 277280.

https://doi.org/10.6000/1929-4409.2021.10.33

Nugroho, D., \& Noho, M. (2020). Kajian Yuridis Kewenangan Pemerintah untuk Memerintahkan Melakukan Merger kepada Entitas Bank pada masa Wabah Covid19 dalam Rezim Perdagangan Internasional,. Cakrawala Hukum, 22(2), 17.

Nurvianti, D. (2017). Accessibility Rights To Public Facilities For Disabilities In Indonesia. Tadulako Law Review, 2(2), 221. https://doi.org/10.22487/j25272985.2017.v2.i2.8945

Pratomo Andi Widodo, A., Hufad, A., \& Sunardi. (2019). Teachers Perception on the Management of Inclusive Education in Elemantary School. Journal of ICSAR, 3(2), 23-25.

Priscyllia, F. (2016). Kajian Hukum Terhadap Fasilitas Pelayanan Publik Bagi Penyandang Disabilitas. Lex Crimen, V(3), 15.

S, M. (2003). Ekonomi Sumber Daya Manusia dalam Perspektif Pembangunan. Jakarta: Raja Grafindo Persada.

Simanjunta, J. G. (2021). Policy on Fulfilling the Rights of Persons with Disabilities in Indonesia: Quo Vadis? Indonesian Journal of Disability Studies, 8(1), 220.

https://doi.org/10.21776/ub.ijds.2021.008.01.16 
Soekanto, S., \& Mamudji, S. (2011). Penelitian Hukum Normatif. Jakarta: Raja Grafindo Persada.

Sumanjoyo Hutagalung, S., \& Faedlulloh, D. (2021). Pro Disability Policy in Local Governments: Lessons from the Central Lampung Regency. Indonesian Journal of Disability Studies, 8(1), 161-177. https://doi.org/10.21776/ub.ijds.2021.008.01.13

Tamba, J. (2017). A Juridical Study Toward Indonesian Disabilities Right For Public Services Accessibility According To Law No. 8 Year 2016. Indonesian Journal of Disability Studies, 4(1), 63-68. https://doi.org/10.21776/ub.IJDS.2017.004.01.9

Tibaka, L., \& Rosdian. (2017). The Protection of Human Rights in Indonesian Constitutional Law after the Amendment of the
1945 Constitution of the Republic of Indonesia. Fiat Justisia, 11(3), 266-288.

https://doi.org/10.25041/fiatjustisia.v11no3.1141

Tri Anomsari, E., \& Widharetno Mursali, S. (2020). Mainstreaming Disability: Challenges and Strategies Towards Equality and Decent Work in Indonesia. Journal of Social Sciences and Humanities, 10(1), 7. https://doi.org/10.31940/soshum.v10i1.1444

Zaman, N. (2017). The Meaning Of Authority Relation Of Central Government And Local Government In The Land Sector According To The 1945 Constitution Of The Republic Of Indonesia. Yustisia, 6(3), 531. https://doi.org/10.20961/yustisia.v6i3.16788

Received on 04-05-2021

Accepted on 26-06-2021

Published on 02-07-2021

https://doi.org/10.6000/1929-4409.2021.10.135

(C) 2021 Warsono and Mashari; Licensee Lifescience Global.

This is an open access article licensed under the terms of the Creative Commons Attribution Non-Commercial License (http://creativecommons.org/licenses/by-nc/3.0/) which permits unrestricted, non-commercial use, distribution and reproduction in any medium, provided the work is properly cited. 